European journal of American studies

\title{
Martin Luther King's Reaction to the Cuban Missile Crisis
}

Leonardo Campus

\section{(2) OpenEdition \\ Journals}

Electronic version

URL: https://journals.openedition.org/ejas/12186

DOI: $10.4000 /$ ejas. 12186

ISSN: 1991-9336

Publisher

European Association for American Studies

\section{Electronic reference}

Leonardo Campus, "Martin Luther King's Reaction to the Cuban Missile Crisis", European journal of

American studies [Online], 12-2 | 2017, Online since 30 October 2017, connection on 08 July 2021. URL: http://journals.openedition.org/ejas/12186 ; DOl: https://doi.org/10.4000/ejas.12186

This text was automatically generated on 8 July 2021.

Creative Commons License 


\title{
Martin Luther King's Reaction to the Cuban Missile Crisis
}

\author{
Leonardo Campus
}

1 This research article will focus on the reaction of Martin Luther King Jr. to the Cuban missile crisis of October $1962^{1}$, including the presentation of a previously unknown document of particular relevance on such a topic - i.e. a private letter from King to President Kennedy regarding his handling of the situation - and reflecting on some of the aspects raised by the evidence, with particular regard to the relationship between the two leaders.

2 As is well-known, the Cuban missile crisis occurred after the Soviet Union - under the leadership of Nikita S. Khrushchev - secretly deployed medium and intermediate-range nuclear missiles in Cuba. The discovery of these installations by U-2 photoreconnaissance missions (October 16, 1962), led the US government under the Kennedy Administration to impose a naval blockade on Cuba - euphemistically called a "quarantine" to give it an appearance of international legality. This was accompanied by an official request for the removal of the missiles already in Cuba, and an explicit threat of a "full retaliatory response upon the Soviet Union", should any of those missiles be launched. Such policy was announced by President Kennedy in a TV address on 22 October $1962 .{ }^{2}$ On 28 October, after days of extreme international tension and a real danger of escalation ${ }^{3}$, Khrushchev suddenly agreed to remove the missiles, under two conditions. One, an American guarantee that it would not invade Cuba; and two, the removal of US nuclear missiles from Turkey after a few months (this condition was secretly conceded by Kennedy).The crisis was later defined by historian (and Kennedy's aide) Arthur Schlesinger, Jr as "the most dangerous moment in human history".

\subsection{DR. KING'S REACTION}

3 Martin Luther King's reaction to the Cuban crisis was initially dealt with in the context of an article by this author that first investigated the African Americans' responses to said nuclear crisis $^{5}$. While we refer to that paper for a picture on that general context, 
here it must be recalled that the overall reaction among African Americans was one of solid and widespread support - consistent with that of general American public opinion $^{6}$, but in measures and tones that may appear remarkable considering the unprecedented dangers that the crisis implicated and the harsh struggle for civil rights that was then ongoing on the domestic front. More specifically, said reactions tended to combine a widespread support for the President in a time of national crisis with a strong desire for the preservation of peace.

4 In this context, the position taken by Martin Luther King occupies a special and fitting place. Special for its relevance, given the fact that at the time, while he had not yet been awarded a Nobel prize, he was already the best known activist and the most influential leader of the civil rights movement. Fitting because the views he expressed, if more elaborated and nuanced, appear consistent with the reactions of approval recorded among the majority of the African American public.

5 King's few public statements on the crisis are to be found in the pages of the so-called black press. The Harlem weekly "New York Amsterdam News", for instance, reported that "Rev. Martin Luther King, in New York to address a testimonial dinner, called for special prayers for the President. 'In these critical days we need broad understanding and a faith in the future so that the dream of peace may become a lasting reality'." "We see here the 'dream' image that would later resurface in his well-known speech at the march on Washington. Apparently it was a picture that lay already in the heart of the pastor from Georgia. Content-wise, his statement was cautious but supportive, while unwilling to define his position on the specific measures taken by Kennedy.

On October 24, 1962, as he was invited to speak at the Harvard Law School (a location that might have been receptive to the expression of doubts on the handling of the Cuban crisis), King was careful to stick to the theme of his speech, "The future of integration", without touching on the international situation ${ }^{8}$. He also declined an approach by an emissary of the local student movement for nuclear disarmament - the "Tocsin" - to combine his rally with their own and address them jointly9. It is entirely plausible that the rationale for this refusal was to avoid to be dragged into a protest debate against White House foreign policy.

7 In another comment of those days, King, after confirming to the interviewer the inevitability of correlation between the international crisis and the domestic struggle for civil rights, added laconically: "I am convinced that the U.S. must take a moral offensive as well as military offensive". ${ }^{10}$

8 As can be seen, all the declarations that King released during the course of the crisis were brief and without hints of dissent, and while not being enthusiastic, they steered clear of raising objections. This however was not due to any tendency to court the administration, as confirmed by both his previous public condemnation of the Bay of Pigs invasion (which had taken the form of a strongly critical statement and a signed petition) ${ }^{11}$ and his later protest of the US war in Vietnam (expressed on several occasions, including his famous speech of April 4, 1967) ${ }^{12}$. Apparently, he was simply convinced that the government did not deserve to be criticized in this specific case.

9 On January 5, 1963, a few weeks after the crisis was solved, King returned to the subject in the column he penned twice a month for the "New York Amsterdam News". This time his reflections were more extensively articulated:

Everyone of us knows full well that we came dreadfully close to the precipice of nuclear war in 1962. There is grave danger, however, that our "success"13 in 
handling the Cuban Missile Crisis could be misused. We must not allow the delicate balance that has been established in matters of foreign policy to be destroyed by our arrogance. We would hope that since near disaster has been avoided, America would in humility readily grasp the opportunity to make a determined bid for peaceful co-existence. (...) now is the time for us to concretely seek common agreement on nuclear testing and disarmament. (...) In truth, what more worthy objective could the whole brunt of our energies in foreign policy be expended? ${ }^{14}$

10 As lucid and sensible as these words may seem, they went against the prevailing trend of triumphant lessons being drawn from the outcome of the crisis. According to those opinions, the Soviets had ended up backing down unconditionally as soon as the US had raised their tone, making clear they meant business ${ }^{15}$. King warned such a view was dangerous. Moreover, he appeared to have been a good prophet, not only because the Soviets had actually gained more from the agreement than was publicly known at the time, thus confuting the claims of a total US triumph, but even more so since an international treaty on nuclear tests was effectively achieved a few months later, and détente was the course that Washington and Moscow chose in $1963^{16}$.

11 Finally, a less relevant mention of the Cuban crisis is to be found in passing in an article on civil rights that King published in the spring of $1963 .{ }^{17}$

\subsection{THE LETTER TO PRESIDENT KENNEDY}

12 These views that King expressed publicly on the missile crisis may now be integrated with a previously unknown document that was recently unearthed. It is a private letter from Martin Luther King to President Kennedy on the Cuban missile crisis, that was sent "only a few weeks after [its] resolution". Two copies were found. One is attached to a letter that King's aide Stanley Levison sent shortly before his death to historian (and former Kennedy advisor) Arthur Schlesinger, Jr.. In attaching it, Levison notes: "This has never been made public and I believe aside from myself no one else has seen it". ${ }^{18}$

13 The other copy is enclosed in a letter that Clarence B Jones, King's lawyer and close advisor, sent him on November $1^{\text {st }} 1962$ (i.e., four days after the crisis had eased) to urge him to share with the President his comments on said event ${ }^{19}$. To this end, Clarence prepared for King a draft letter, here quoted in its essential parts.

Because so often as a spokesman for civil rights I have written you to press for programs we felt to be urgent, my personal observations on other subjects, as a private American citizen, have necessarily been limited.

14 King had written Kennedy at least six times since his term began (on March 1, March 16 and December 17, 1961; on March 30, August 2 and August 31, 1962) ${ }^{20}$. Issues related to civil rights were indeed the main topic discussed in all of them. ${ }^{21}$

The resolution of the Cuba crisis with its immense implications is, however, so important, I am eager to express my personal reactions.

At a time when so many are saying that the most impressive achievement is the result, I find myself as much impressed by the method.

By method I do not mean "firmness" or any of the other oversimplified descriptions which mislead rather than clarify. Putting aside the issue of blockade, it was the larger scheme of your basic design which was singular in diplomatic art.

The original quality was in the opportunity it provided for choices to this adversary which could evoke constructive responses. In precisely measuring consequences, the architecture of your initiative, by planning for a not dishonorable doorway, served to bring out a positive quality in Mr. Khrushchev. 
During the course of the crisis Kennedy surely took various steps to allow Khrushchev a way to retreat honorably, though most of them were not publicly known at the time ${ }^{22}$, so here the letter probably referred to the choice of a blockade rather than of a direct air strike, and to the tone of the public messages exchanged with Khrushchev during the crisis.

(...) Finally, in resisting any impulses to overestimate or overstate results, you gave your adversary an opportunity to count some gain, thereby obviating a psychology of desperation.

16 This refers to the input given by Kennedy to the government and the reporters not to gloat over the crisis outcome, lest Khrushchev feel humiliated and refuted the compromise reached. ${ }^{23}$ This reference in the letter closely recalls what King will publicly write a few weeks later in the above-mentioned article for the "New York Amsterdam News" (see above). ${ }^{24}$

This laid a firm basis for future negotiations. Equally, your fair and generous characterization of Mr. Khrushchev's responses as "statesmanlike" created an example for him.

In the combination of these approaches, I feel you have utilized some of the elements of non-violent creativity in international conflict, despite the presence of latent force. Non-violent resistance has so much spiritual power because it unremittingly pursues its goal and yet it recognizes that every opponent somewhere has a receptive syndrome which may lead to reconciliation, even if presently limited in dimension.

Something vastly more important seems to have occurred than a bases-invasion quid pro quo. You may well have reached into the deep recesses of a divided world and found a bridge of accommodation (...) A world armed and over-armed on both sides with ultimate weapons cannot find security or survival in multiplied power. Hope is only in the realization that there is a final point of restraint both sides must observe.

I hope you will continue, despite contrary pressures, to pursue the difficult quest for settlements (...).

In this direction may be the greatest achievement of the twentieth century - the emergence of statesmen who are equal to the colossal risks a racing technology has imposed upon the world. (...)

17 Was this letter eventually sent? Did King just sign the draft, without modifying its substance? And did Kennedy ever reply to it? Levison's letter shows no doubt on such questions. He writes that the "letter" (not draft) was "sent", and adds: "I am trying to get Kennedy's response from Martin's still unprocessed papers. Dora, Martin's secretary, was to send me the reply at the time but it was sidetracked and I never saw it nor do I know the nature of his response" 25 . Nor has Clarence B Jones himself ever expressed any contrary opinion, in our repeated email exchanges on the subject, though unwilling to provide further details ${ }^{26}$. Besides, King usually valued Jones' advices, defining him "a man of sound judgment, deep insights, and great dedication". ${ }^{27}$ This seems confirmed also by the various important tasks he performed in the years (1960-1968) in which he worked for dr. King, a number of which were as a contributing speechwriter. ${ }^{28}$

18 On the other hand, it is also not impossible that this specific Jones' initiative was eventually put aside by King for some reason, and that later Levison in all good faith mistook a draft for a delivered letter. In this sense, the fact that Schlesinger, while receiving the letter, did not pursue its publication ${ }^{29}$ and the fact that, more recently, a footnote of Volume VII of Dr. King's papers edition passingly referred to the item as a 
"draft statement" ${ }^{30}$ rather than as a letter, may suggest prudence in considering the text as surely sent, or sent in this form ${ }^{31}$.

However, the letter appears fully consistent with King's other comments on the crisis, as discussed above. Also, Jones writes to King that his "suggested text incorporates thoughts you have expressed on this subject" 32 . This remark grants relevance to the document even should one suppose that it was not eventually sent or that it was sent in modified form, because it would still contribute to shedding more light on King's views of the Cuban crisis.

20

A few points of the text must be highlighted. King's description (via Jones) of Kennedy's policy as an example of "non-violent creativity in international conflict" is surely striking, considering that such actions - no matter how politically comprehensible in light of the Soviet provocation and how less drastic than other alternatives considered in the Ex-Comm ${ }^{33}$ such as air-strikes or invasion of Cuba - included military measures (of dubious international legality) which contributed significantly to the most dangerous nuclear crisis that ever occurred ${ }^{34}$. This explains the immediate mitigation of such a statement ("despite the presence of latent force") and the veiled doubts expressed on the use of a naval blockade ("putting aside the issue of blockade") and on common oversimplifications regarding the presumed benefits of firmness (a term significantly put between quotation marks, just as the term 'success' in his later article on the crisis, mentioned above). King's use of "despite" and "putting aside" to characterize the blockade and the threatened use of force, instead of "in force of them" or "thanks to their combination with negotiation" marks an implicit yet significant difference with the prevailing interpretation of Kennedy's handling of the Cuban crisis, widely seen in those days as a perfect mix of diplomacy and military power.

Still, such a passionate support of Kennedy's handling of the crisis was not one to be taken for granted, coming from a leader who only months before had publicly condemned the White House for the Bay of Pigs invasion, besides having criticized it as well for its reluctance to act on civil rights issues ${ }^{35}$.

At the same time, the text correctly emphasized the deep symbolic and political value of compromise with the adversary and of the way it was reached.(which had indeed points in common with King's previous definitions of nonviolent principles $\left.{ }^{36}\right)$.The general aim of the letter seemed to convey to the President a word of personal, even spiritual backing, encouraging him to pursue détente "despite contrary pressures" ${ }^{37}$. Eventually this would prove to be the path Kennedy took in the final months of his presidency.

\subsection{DR.KING'S NONVIOLENCE}

Moreover, should it be confirmed that it was sent in this form, the letter would also provide evidence of the fact that King promoted non-violent methods (or what he saw as such) not only in civil rights issues (a field in which he personally practiced them) but also in the field of international relations. As he had written at the time of the Bay of Pigs, "I am as concerned about International affairs as I am about the civil rights struggle in the United States". ${ }^{38}$ 
King had first discovered Gandhian non-violent methods as a student of theology in the spring of 1950, successfully practiced them in the Montgomery bus-boycott in 1955-1956 and further absorbed and embraced them after his trip to India in $1959 . .^{39} \mathrm{In}$ foreign affairs, he had consistently favored nuclear disarmament and opposed nuclear tests at least since December 1957. In an article of January 1962 King defined "nonviolence in the nuclear age" as "life's last chance". ${ }^{40}$

Moreover, Dr.King's insistence on the importance of non-violence in foreign affairs and on seeking "common agreement on nuclear testing and disarmament" (to use King's exact words taken from his above-mentioned article on the New York Amsterdam News) seems perfectly consistent also with the growing 'anti-Bomb' efforts carried out a the time by women, liberal and pacifist groups (such as the War Resisters League ${ }^{41}$ ), joined by large portions of African-Americans civil rights activists who had been fighting consistently for such issues since $1945^{42}$. This meant that activists of said groups often campaigned for both goals: race equality at home and nuclear détente abroad $^{43}$, seeing them as closely linked, through the issue of colonialism. ${ }^{44}$

This can also be seen in an 'intermestic' perspective (i.e, international + domestic) ${ }^{45}$. Not in the sense that partisan internal politics influenced the handling of foreign affairs by leaders, but on the contrary in the sense that groups pressing for desegregation at home were also campaigning for a stop to the arms race and for détente in foreign affairs, seeing the two issues as linked ${ }^{46}$. In this regard the position assumed by King (via Jones) in this letter would appear emblematic.

27 .

Incidentally, regarding the interconnections between issues of colonialism, foreign affairs and race relations, it should be added that in mid-October King had a long and warm meeting with Ben Bella, the leader of the newly decolonized country of Algeria. As King himself revealed in an article published in the midst of the nuclear crisis, ${ }^{47}$ the two leaders discussed 'issues ranging from the efficacy of non violence to the Cuban crisis' ${ }^{48}$ While not implying any causal connection, the fact that in those same weeks King had discussed the usefulness of non-violence with a prominent foreign leader can be seen as a further confirmation that the topic was indeed particularly present and relevant in King's mind also in that very period. moral dilemmas of political ethics in the nuclear era also among several other clergy members and theologians of different confessions, both in the US and abroad. ${ }^{49}$ The variety of their reactions confirms the value of a study of the so far neglected sociocultural dimension of said crisis, based on ways it was perceived and the reactions it produced.

\subsection{THE RELATIONSHIP WITH KENNEDY}

30 The letter may also prove significant for what it tells us on the relations between King and Kennedy on two major points.

First, King seemed convinced that he and the President shared a similar idea of leadership: not one of simple firmness or machismo towards the opponent, but one seeking solutions through negotiation, though with a boldness to take risks to bring those results about. This is plainly evident in King's methods to force racial integration 
on US society through actions of civil disobedience but without recurring to violence (in contrast with the radical approach of other civil rights leaders refuting the goal of integration and accepting violent protests); and evident in Kennedy's resistance to pressures coming from the "hawks" in the Ex-Comm and in the Pentagon for ordering a military attack in the Cuban crisis $^{50}$, in his refusal to accept the widespread equivalence between "negotiation with enemy" and "appeasement", and in his repeated recourse to back-channel negotiators in order to peacefully defuse standoff situations with Khrushchev (such as sending his brother Robert to talk secretly with the Soviet agent Georgi Bolshakov during the crisis at Berlin's Checkpoint Charlie in 1961, or with the Soviet Ambassador Anatoly Dobrynin on October 27 at the peak of the Cuban crisis, in addition to pre-alerting the academic Andrew Cordier as conveyer of a secret message to UN Secretary U Thant containing the proposal for the compromise ${ }^{51}$ ). Even without knowing all of these details, King notices and praises this attitude by Kennedy perhaps even more because he knew how the political milieu at the White House and in foreign policy circles was then centered on an ideology exalting toughness and masculinity, rather than virtues of restraint, moderation or wise prudence, as historian Robert Dean has demonstrated. ${ }^{52}$

Second, King appeared to have a fundamental and growing trust in Kennedy (who reciprocated it), in spite of all the frustrations and criticisms over his reluctance to act resolutely on civil rights issues ${ }^{53}$. King was convinced that JFK's quality as a leader was evolving, becoming bolder. As he will explain after the President's assassination, he believed he had known two different John Kennedys. "One", he said, "presided in the first two years under pressure of the uncertainty caused by his razor-thin margin of victory. In 1963, a new Kennedy had emerged. He had found that public opinion was not in a rigid mold. He was, at his death, undergoing a transformation from a hesitant leader with unsure goals to a strong figure with deeply appealing objectives." ${ }^{54}$ Obviously King could cooperate more with this second, bolder Kennedy and over the course of 1963 his relations with the President grew stronger, being based on a deeper mutual trust in each other's commitment ${ }^{55}$. And as one reads this letter of praise where King says (or at least is claimed by Jones) to be "most impressed" by the President's methods, one cannot help but think that Kennedy's efforts to avoid an escalation in the Cuban crisis played an important, early role in shaping this idea of an evolving Presidential leader in King's mind. So it can be argued that Kennedy's handling of the Cuban crisis is likely to have been one of the major steps that contributed to the late (re)assessment of President Kennedy by Martin Luther King, of course together with his later TV address of 11 June 1963 on civil rights as a moral issue the country needed to confront. ${ }^{56}$ Levison's words to Schlesinger also points in the same direction of an evolving relationship between the two leaders. ${ }^{57}$

Future publications ${ }^{58}$ might be in a position to add new elements clarifying the letter's practical context, or to locate the presidential reply claimed by Levison ${ }^{59}$. Until then, clearly a degree of prudence remains advisable before automatically attributing to King every term of this draft letter (as we currently have only one source - his trusted aide Levison - claiming it was sent in that form, though none has denied it either). It seems already useful, however, to present this new document with all the elements currently available, considering its obvious relevance, for its content, the leaders involved, and because it integrates the picture of Dr. King's reactions to the crisis and his relationship with President Kennedy. 
As for the other positions taken by King on the Cuban crisis, they are also of great interest, as discussed above (Section 1.1). They stand out in particular for their initial laconic prudence and their absence of criticism of Kennedy during the crisis (at that critical juncture, King appears to see the President as someone to pray for, rather than someone to judge or debate upon), and later for their political lucidity in warning against any indulgence in national arrogance or self-complacency while pointing toward the post-crisis new opportunities of fruitful negotiations for nuclear disarmament and détente.

36

\section{NOTES}

1. The Cuban missile crisis represented a turning point in the Cold war and in the nuclear age. Literature on that superpower confrontation is vast and growing. Among the many works, see Ernst R. May, Philip D. Zelikow, The Kennedy Tapes: Inside the White House during the Cuban Missile Crisis (Cambridge: Belknap Press of Harvard University Press, 1997); Sheldon M. Stern, Averting the Final Failure: John F. Kennedy and the Secret Cuban Missile Crisis Meetings (Stanford: Stanford University Press, 2003); Aleksandr Fursenko, Timothy Naftali, One Hell of a Gamble: The Secret History of the Cuban Missile Crisis (New York: W.W. Norton \& Co., 1997); Tomas Diez Acosta, October 1962. The 'Missile' Crisis as seen from Cuba, (New York: Pathfinder, 2002); Michael Dobbs, One minute to Midnight. Kennedy, Khrushchev and Castro on the brink of nuclear war (New York: Knopf, 2008); Alice George, Awaiting Armageddon. How Americans faced the Cuban Missile Crisis (Chapel Hill: University of North Carolina Press, 2003); The Global Cuban Missile crisis at 50, CWIHP Bulletin, No.17/18, Fall 2012; Leonardo Campus, I sei giorni che sconvolsero il mondo. La crisi dei missili di Cuba e le sue percezioni internazionali (Firenze: Le Monnier, 2014); Len Scott, Gerald Hughes (eds.), The Cuban Missile Crisis: A Critical Reappraisal (New York: Routledge, 2015).

2. The full text of the address is in Laurence Chang, Peter Kornbluh, eds., The Cuban Missile Crisis - A National Security Archive Documents Reader (New York: The New Press, 1998), 163.

3. More specifically, diplomatic historian James Hershberg recently argued that while "probably the peril of intentional escalation was less acute than once formerly believed (...) the risk of inadvertent escalation appears to have been even greater". James G. Hershberg, The Cuban missile crisis, in Melvyn P. Leffler, Odd Arne Westad (eds.), The Cambridge History of the Cold War (Cambridge: Cambridge University Press, 2010), Vol.2, 65-87

4. Arthur Schlesinger, Foreword, in Robert Kennedy, Thirteen days. A memoir of the Cuban missile crisis (New York: W.W. Norton, 1999 edition), 7.

5. Leonardo Campus, "Missiles have no colour: African Americans' reactions to the Cuban missile crisis", Cold War History, 15, 1 (February 2015): 49-72

6. On the crisis perceptions in the US and the reactions of the press and among the intellectuals, see Campus, Giorni, 147-231. A special survey carried out nationally by Gallup just hours after the 
President's TV speech recorded that, among those who listened to it, $84 \%$ approved of his decision, $12 \%$ refused to express an opinion, while only $4 \%$ disapproved. Tom V. Smith, "The Cuban Missile Crisis and U.S. Public", Public Opinion Quarterly, 67 (Summer 2003): 271. Also, among the several thousands messages that citizens sent to the White House, the ratio was 22 in favour to 1 against. George, Awaiting, xviii

7. "Harlemites Backing President's Stand", New York Amsterdam News, 27 October 1962, 1

8. "Struggle for integration must continue, King says", Crimson, 25 October 1962.

9. This detail comes from the organizer of the Tocsin rally, the activist Todd Gitlin, future President of the Students for a Democratic Society. Todd Gitlin, The Sixties - Years of hope, days of rage (New York: Bantam, 1987), 99

10. Jet, 8 November 1962 , 17. Incidentally, this comment was quoted later by the militant activist in exile Robert Williams in his newsletter from Cuba, with the word 'military' put in capital letters, in criticism of King's supposed non-violent attitude. The Crusader, 4, 5 (January 1963): 3. Robert F. Williams papers. M4389, Reel 11, Group 1, Series 7, John F. Kennedy Institute for North American Studies, Berlin.

11. In May 1961, answering a letter he received from Barbara Lindsay, King had said: "I think our country has done not only a disservice to its own citizens but to the whole of humanity in dealing with the Cuban situation. ... Unless we as a nation join the revolution, and go back to the revolutionary spirit that characterized the birth of our nation, I am afraid that we will be relegated to a second-class power in the world with no real moral voice to speak to the conscience of humanity." King also added his name to a petition condemning the attempted invasion. Brenda Gayle Plummer, Castro in Harlem: A Cold War Watershed, in Allen Hunter, ed., Rethinking the Cold War: Essays on Its Dynamics, Meaning, and Morality (Philadelphia: Temple University Press, 1997), 147; Brenda Gayle Plummer, Rising Wind. Black Americans and US Foreign Affairs, 1953-1960 (Chapel Hill: University of North Carolina Press, 1996), 305. (The latter also documents a similar criticism of that invasion coming from the black press too).

12. Adam Fairclough, Martin Luther King, Jr. and the War in Vietnam, in Michael Krenn, ed., The African American Voice in U.S. Foreign Policy Since the World War II (New York: Garland Publishing, 1998), 255-277. Clayborne Carson, Tenisha H. Armstrong, Susan A. Carson, Erin K. Cook, Susan Englander, The Martin Luther King, Jr., Encyclopedia (Wesport: Greenwood, 2008). In 1968, five days before his death, King added that the US war in Vietnam was "one of the most unjust wars that has ever been fought in the history of the world".

13. The quotation marks here suggested some doubts on the suitability of a term that was recurrent in the international public debate of those weeks.

14. Martin Luther King, "New Year Hopes", The New York Amsterdam News, 5 January, 1963

15. On this post-crisis triumphalism George, Awaiting, xxii, 104; Campus, Giorni, 149-152. Said triumphalism was particularly visible in the press of those days (one example being Joseph Alsop's editorial on the New York Hearld Tribune, titled “Victory!"),See also Dobbs, Midnight, 337 and Richard Reeves, President Kennedy. Profile of power (New York: Simon \& Schuster, 1993), 426. Reeves mentions “The United States' sense of triumph in Cuba" and reports the poll documenting Kennedy's rise in approval rates, jumping from 66 to $77 \%$ after the Cuban crisis.

16. The Limited Test Ban Treaty was signed in Moscow on August 5, 1963. Before the Cuban crisis, it had been unfruitfully negotiated for years in Geneva. It was the first international agreement over nuclear arms control. On US-USSR relations in 1963, see Michael Beschloss, The crisis years, 1960-1963 (New York: E. Burlingame Books - Harpercollins, 1991), 546-641. Consensus among scholars on the impact of the Cuban crisis on 1963 détente and negotiations of the LTBT is wide. See also, for instance, Arthur Schlesinger, Jr., Robert Kennedy and His Times (New York: Houghton Mifflin, 1978) 530. David Holloway, Nuclear Weapons and the escalation of the Cold War, 1945-1962, in Cambridge, Vol. 1, 397; Campbell Craig, Fredrik Logevall, America's Cold War, The politics of insecurity (Cambridge: Harvard University Press, 2009),212-213. For a partially 
different opinion, see Dario Fazzi, "The Blame and the Shame: Kennedy's Choice to Resume Nuclear Tests in 1962", Peace Change, 39: 1-22,16).

17. In the annual report on civil rights that he published on 'The Nation', King lamented that 1962 was "the year that civil rights was displaced as the dominant issue in domestic politics", though acknowledging that " 1962 was the year of the Cuban crisis, which understandably tended to dwarf all other issues." Martin Luther King, "A Bold design for a new south", The Nation, March 30, 1963, 259-262. The article is also available here: www.thekingcenter.org/archive/ document/bold-design-new-south

18. Letter from Stanley Levison to Arthur Schlesinger, Jr., + Attached, 7 December, 1978, in Box 403, Folder RFK, A. Schlesinger Papers, Manuscript and Archives Division, New York Public Library. The previous quote also comes from this Levison letter.

19. In his letter to King, Jones noted that two positions existed: "On the one hand, there are those who feel someone of 'Dr. King's stature' should say something 'forcefully' on the Cuban crisis, while, on the other hand, there are those who think that you have only a narrow concern for civil rights and, therefore, have no definitive thoughts or position on the matter." He believed both groups missed the point. So he proposed King a text to be sent as a private letter to Kennedy. He argued that " (...) at least if no statement is issued by you to the public at large on the Cuban crisis, it would be significant, in our judgment, that your reaction to the present Cuban crisis be made knew to the President of the United States. (...) your status as a leader requires that you not be silent about an event and issues so decisive to the word". Jones also strongly regretted "that virtually every other Negro leader of stature has been silent on this question, to their discredit". Finally he suggested to have the letter delivered to the President through Burke Marshall (Assistant to the Attorney General Robert Kennedy and in charge of civil rights matters), or alternatively through Andrew Hatcher (Assistant to the White House Press Secretary, the first African American to hold such position). Letter from Clarence B. Jones to Martin Luther King, Jr., Nov. 1, 1962, in Box 32, Folder 5, The Martin Luther King, Jr., Collection, Howard Gotlieb Archival Research Center, Boston University.

20. Clayborne Carson, Tenisha H. Armstrong, eds., The papers of Martin Luther King, Jr., Vol. VII (Oakland: University of California Press, 2014), xix-xxi, 172, 175, 349, 606; The King Center online database: www.thekingcenter.org/archive/document/telegram-mlk-president-john-f-kennedy

21. With the partial exception of the letter dated March 17, 1961, in which King also congratulated Kennedy for his election before asking to meet with him to discuss civil rights ("within the next three or four weeks". The meeting did not happen until October 16). Carson, Armstrong, eds., Papers, VII, 175

22. See for instance: Beschloss, Crisis, 506; Robert Kennedy, Thirteen days (New York: W.W. Norton, 1968), 98; Sheldon Stern, The week the world stood still (Stanford: Stanford University Press), 112.

23. Beschloss, Crisis, 542; Dobbs, Minute, 337.

24. In December, the editorial of the African American newspaper "Chicago Defender" would also give credit to the President for having "shown the country a good example by refusing to gloat over the Soviet Union's backdown in Cuba". It also advised its readers to indulge in "neither bluster nor braggadocio". "The Voice of Wisdom", Chicago Defender, 11 December, 1962, 12.

25. Stanley Levison to Arthur Schlesinger, Jr., attached, in Box 403, Folder RFK, A. Schlesinger Papers, Manuscript and Archives Division, New York Public Library.

26. He promised to send us "a simple statement confirming the authenticity of the document" (Email to the author, 13 October, 2011). Ultimately, however, he was unable to provide details, despite repeated invitations and questions on our part to help clarify the matter for historical accuracy.

27. The Martin Luther King, Jr., Encyclopedia (Westport: Greenwood Press, 2008), 164. On May 29, 1962, King had also written a letter of recommendation for Jones, affirming: "Ever since I have 
known Mr. Jones, I have always seen him as a man of sound judgment, deep insights, and great dedication. I am also convinced that he is a man of great integrity". http:// kingencyclopedia.stanford.edu/encyclopedia/encyclopedia/

enc_jones_clarence_benjamin_1931/.

28. Clarence B Jones was born in 1931. In 1960 he joined the team of lawyers defending Martin Luther King. In 1963, as the Georgian pastor was jailed in Birmingham for demonstrating during that civil rights campaign, Jones secretly took King's manuscript, that was then to be published and become famous as 'Letter from Birmingham jail'. He also contributed to the first drafting of the noted speech King delivered during the March of Washington and later to King's speech against Vietnam war of April 4, 1967 (together with Vincent Harding and Andrew Young). http:// kingencyclopedia.stanford.edu/encyclopedia/encyclopedia/

enc_jones_clarence_benjamin_1931/; $\quad$ http://www.thekingcenter.org/archive/theme/2646 Incidentally, a scholarly debate has developed around King's authorship issues, mostly due his (posthumously discovered) plagiarism of portions of his PhD thesis. However this is not of direct relevance here, as King's frequent use of speechwriters and ghostwriters (such as Jones and Levison) as a civil rights activist simply followed a common practice among public orators and prominent leaders in general. On these issues, see David J. Garrow, "King's Plagiarism. Imitation, Insecurity and transformation", The Journal of American History,78, 1 (June 1991): 86-92.

29. This however is just a speculative hypothesis, and while the choice by Schlesinger of not pursuing the letter's publication may in theory be linked also to doubts over its 'delivered' status, there are no elements to support this case and it seems more plausible that his choice was based simply on different research priorities. In particular, having already written two big books on the Kennedy brothers and their times, each containing chapters on civil rights and on their relations with King, Schlesinger may well have decided not to return on such topics. (The second of said books in particular - Robert Kennedy and his times - had just been published as he received the document from Levison in 1978).

30. Our italics.

31. It must be born in mind, though, that said footnote is meant to be only a generic reference, made in passing, as also shown by the fact that the text in question is clearly that of a letter, not of a "statement". Carson, Armstrong, eds., Papers, VII, 215. The volumes of this broad project are published in chronological order, along several years, and the one covering the period of the Cuban crisis has not been released yet.

32. Letter from Clarence B. Jones to Martin Luther King, Jr., 1 Nov., 1962, in Box 32, Folder 5, The Martin Luther King, Jr., Collection, Howard Gotlieb Archival Research Center, Boston University.

33. The Executive Committee of the National Security Council (Ex-Comm) was the group of government officials and experts that President Kennedy gathered upon the discovery of Soviet missiles in Cuba to advise him on the handling of the situation. It met regularly during the course of the crisis.

34. Consider for instance sharply contrasting comments on the same policy, such as this telegram sent to the President by the Nobel prize chemist and activist Linus Pauling (cosigned by his wife): "Your horrifying threat of military action on shipping on the high seas and possible massive retaliation by nuclear attack to any resistance places all the American people as well as many people in other countries in grave danger of death through nuclear war. (...) we strongly urge that you immediately withdraw your belligerent orders and threats (...)". Linus Pauling and Ava Helen Pauling to John Fitzgerald Kennedy, 22 October, 1962, in Box 1962a3, Folder 3.2, Ava Helen and Linus Pauling Papers, Oregon State University Libraries, Manuscripts of Articles. On Pauling's reaction, see Campus, Giorni, 376-378

35. For instance on his article of March 3, 1962 for "The Nation", significantly titled "Fumbling on the New Frontier", Martin Luther King had described Kennedy's policy on civil rights "cautious and defensive", "characterized by inadequacy and incompleteness", and added: "It is a 
melancholic fact that the Administration is aggressively driving only toward the limited goal of token integration". Carson, Armstrong, eds., Papers. VII, 412

36. Particularly the letter's description of how Kennedy planned a not dishonorable doorway for Khrushchev, then avoided overstating the good results and generously characterized his opponent as a statesman in order to bring out positive quality in him and laying basis for future negotiations does closely echo the second of the six principles of nonviolence that King had set forth in his own book, namely that "nonviolence (...) does not seek to defeat or humiliate the opponent, but to win his friendship and understanding." Martin Luther King, jr., Stride toward freedom. The Montgomery Story (New York: Harper \& Row, 1958), 102.

37. This aim is also explicit in Jones' letter: "It is probable that, to some extent, by expressing your views you may be able to support and influence the President to a positive and constructive action". Letter from Clarence B. Jones to Martin Luther King, Jr., 1 Nov., 1962, in Box 32, Folder 5, The Martin Luther King, Jr., Collection, Howard Gotlieb Archival Research Center, Boston University.

38. Letter from King to Barbara Lindsay, May 4, 1961, reproduced in Carson, Armstrong, eds., Papers, VII, 215-216.

39. Clayborne Carson (ed.), The Autobiography of Martin Luther King, Jr., (New York: Warner Books, 1998), 17, 23-24, 121-134. See also http://kingencyclopedia.stanford.edu/encyclopedia/ encyclopedia/enc_nonviolent_resistance/.

40. Vincent J Intondi, African Americans against the Bomb. Nuclear Weapons, Colonialism and Black Freedom Movement (Stanford: Stanford University Press, 2015), 63-66. Already in 1958 he had written: "the choice today is no longer between violence and nonviolence. It is either nonviolence or nonexistence". Quoted in Clayborne Carson, Tenisha H. Armstrong, Adrienne Clay, Susan Carson, Kieran Taylor, eds., The papers of Martin Luther King, Jr., Vol. V (Oakland: University of California Press, 2005), 343.

41. On the War Resisters League, see Scott H. Bennett, Radical Pacifism: The War Resisters League and Gandhian Nonviolence in America, 1915-1963 (Syracuse: Syracuse University Press, 2003).

42. V. Intondi, African Americans. Two clear examples of this will suffice. One is Coretta King, who in addition to the struggle for race equality she shared with her husband, had long been a committed campaigner for groups such as the WILPF (Women's International League for Peace and Freedom), WSP (Women Strike for Peace) and SANE (National Committee for a Sane Nuclear Policy). Intondi, African Americans, 67-70. The other is Bayard Rustin, both a leading civil rights activist and a member of the War Resisters League (WRL). During the Cuban crisis, Rustin organized the largest peace rally of the week in the US, gathering between 8.000 and 10.000 people in front of the UN building, on October 28, 1962. L. Campus , Giorni, 179, 182, 183; Lawrence Wittner, Resisting the Bomb, The struggle against the bomb - A history of the world nuclear disarmament movement, Vol. II (1954-1970) (Stanford: Stanford University Press, 2007) 259.

43. In other words, their two-fold struggle was for desegregation, not disintegration, as in the title of one the most relevant chapters of V. Intondi's book.

44. An example of this is in Rustin's 1959 mission to Ghana to try to stop French nuclear testing being conducted in the Sahara desert, or in the message of support sent by the NAACP (National Association for the Advancement of Colored People) to the delegates at the 1955 Asian-African Conference in Bandung. V. Intondi, African Americans, 4, 51-57, 46-47.

45. C. Craig, F. Logevall, America's, 10-12, 240, 363

46. On the interconnection between civil rights and foreign affairs, segregation, and colonialism in that phase of the Cold war, see for example Brenda Gayle Plummer, In Search of Power. African Americans in the Era of Decolonization, 1956-1974 (Cambridge: Cambridge University Press, 2013); Thomas Borstelmann, The Cold War and the Color Line: American Race Relations in the Global Arena (Cambridge: Harvard University Press, 2001); Mary L. Dudziak, Cold War Civil 
Rights: Race and the Image of American Democracy (Princeton: Princeton University Press, 2000); Michael L. Krenn (ed.), Race and U.S. Foreign Policy from the Colonial Period to the Present: A Collection of Essays (New York: Garland Publishing, 1998), particularly Vol.4 and 5; Thomas Borstelmann, The Cold War and the Color Line: American Race Relations in the Global Arena (Cambridge, MA: Harvard University Press, 2001).

47. Martin Luther King, "My talk with Ben Bella", The New York Amsterdam News, Oct. 27, 1962. The article is quoted in Lewis V. Baldwin, To make the wounded whole. The cultural legacy of Martin Luther King, jr (Minneapolis: Fortress Press, 1992), 176. A typed draft of the article is also available here: www.thekingcenter.org/archive/document/ben-bella-conversation

48. Of course this last remark must be understood as referring to the situation of mounting tension related to the general Soviet military build-up in Cuba which was going on since the summer, not yet to the missile crisis itself, considering that Bella left the US en route to Cuba on the morning of October 16, precisely when the photo-evidence of the presence of Soviet ballistic missiles in Cuba was being secretly communicated to Kennedy himself. So Bella and King could not have been already aware of this new development when they met.

49. Among them, Reinhold Niebuhr, Paul Tillich, Billy Graham, A.J. Muste, Thomas Merton. Aldo Capitini, Donald Soper. On the reactions of religious and nonviolent exponents or groups, see Campus, Giorni, 165-166, 251-273, 345-346.

50. In this regard, see among others Stern, Week.

51. Richard Reeves, President Kennedy. Profile of power (New York: Simon \& Schuster, 1993), 251, 420; Robert Dallek, An unfinished life. John F. Kennedy, 1917-1963 (New York: Little, Brown and Company, 2003), 569

52. Robert Dean, Imperial Brotherhood. Gender and the making of Cold War Foreign Policy (Amherst: University of Massachusetts Press, 2001). In this regard, the attack on Adlai Stevenson for advising the President to advance specific negotiation proposals to Khrushchev seems to us symptomatic. (On said attack, see Mark White, "Hamlet in New York: Adlai Stevenson during first week of the Cuban Missile Crisis", in Illinois Historical Journal, 86, 2 (Summer 1993); Lawrence Freedman, Kennedy's wars (New York: Oxford University Press, 2000) 206, 220).

53. On this reluctance, see, for instance, Mary L. Dudziak, Cold War Civil Rights: Race and the Image of American Democracy (Princeton: Princeton University Press, 2000), 155; Arthur M. Schlesinger, Jr., A Thousand Days. John F. Kennedy in the White House (Boston: Houghton Mifflin Company, 1965), 930; Evan Thomas, Robert Kennedy: His Life (New York: Simon \& Schuster, 2000), 240-241; King himself had publicly criticized the government for this (see above). The same assessment was voiced by the black press: "As the year 1962 came to a close, there were still wide-spread feelings among Negroes that the Kennedy Administration was moving too slowly in the area of civil rights." "Negro Progress in 1962", Ebony (January 1963), 85. On the final legacy of the Kennedy administration on civil rights, historians disagree. For a negative assessment, see for instance Dallek, Unfinished; for a positive one, by James Giglio, see James Giglio, Stephen Rabe, Debating the Kennedy Presidency, (Lanham: Rowman \& Littlefield, 2003).

54. T. George Harris, "Eight Views of JFK: The Competent American", Look, 17 November, 1964 (The relevant section of this article - "Martin Luther King: It's a difficult thing to teach a President" - is reproduced in Rabe, Giglio, Debating, 190-193).

55. Four examples of this, in chronological order: King's telegram to Kennedy to compliment him for his TV address to the nation on civil rights issues of June 11, 1963, that he later defined "the most eloquent, passionate and unequivocal plea for civil rights, for justice toward the Negro ever made by any President" (Michael O'Brien, John F. Kennedy, New York: St. Martin's, 2005, 839); the chat in the Rose Garden that JFK had with King on June 22, 1963, during which the President privately revealed King that he was "under very close surveillance" by the FBI, asking him "to be careful" (Reeves, Kennedy, 530-532; Giglio, Rabe, Debating, 161); the conclusion JFK drew at the end of the same meeting regarding the effort that they were initiating to passing a civil rights bill 
at the Congress: "This is a very serious fight. (...) What is important is that we preserve confidence in the good faith of each other. (...) We will undoubtedly disagree from time to time on tactics. But the important thing is to keep in touch". (Schlesinger, A thousand days, 745); the empathic way in which Kennedy greeted King after the march of Washington ("I have a dream", he said in welcoming him at the White House). After Dallas, King also recalled telling the President frankly that he didn't want "to be in the position that I couldn't criticize him if I thought he was wrong". To which Kennedy replied: "it often helps me to be pushed". (Both episodes come from T.G. Harris, 'Eight Views of JFK: The Competent American', Look, 17 November, 1964)

56. In this TV address to the nation, for the first time Kennedy posed the civil rights problem in moral, rather than only legal or local terms, and announced his intention to ask the Congress to enact a bill on civil rights. https://www.jfklibrary.org/Asset-Viewer/ LH8F_0Mzv0e6Ro1yEm74Ng.aspx (Full video and transcript of the speech). To be complete, it should also be recalled that already in late September 1962, the Kennedy brothers had acted to ensure the enrollment of the African American James Meredith into the thus-far segregated University of Mississippi in Oxford, also known as 'Ole Miss'. In theory this may have made civil rights activists slightly friendlier to Kennedy's Cold War initiatives of the following weeks. However, there is currently no specific evidence of said episode having had any impact on Dr. King's personal assessment of the Presidential handling of the Cuban crisis, unlike the case of some other African Americans observers (see Campus, Missiles, 56, 71). On the 'Ole Miss' crisis, see Frank Lambert, The Battle of Ole Miss: Civil Rights v. States' Rights (New York: Oxford University Press, 2009), Charles W. Eagles, The Price of Defiance: James Meredith and the Integration of Ole Miss (Chapel Hill: University of North Carolina Press, 2009)

57. King's close aide and friend writes the historian that regarding race relations "both [the Kennedys] brothers, scandalously ignorant at the outset, pushed their way to a new perception that was more than the time-worn reformism". This, he concludes, "explains the de facto alliance they fashioned with Martin and his movement". Stanley Levison to Arthur Schlesinger, Jr., + attached, in Box 403, Folder RFK, A. Schlesinger Papers, Manuscript and Archives Division, New York Public Library.

58. For instance C.B. Jones' forthcoming autobiography or the next volume of The papers of Martin Luther King, Jr., that, proceeding chronologically, should also cover the period of the Cuban crisis.

59. Our search in the archives of the Kennedy Library and in the online document databases of the Howard Gotlieb Archival Research Center in Boston, of the King Center in Atlanta and of the King's Institute at Stanford found no such reply.

\section{ABSTRACTS}

This research article deals for the first time with the reaction of Martin Luther King Jr. to the Cuban missile crisis of October 1962. In doing so, it also presents a document of special relevance: the draft of a previously-unknown private letter from dr. King to President Kennedy, in which the civil rights leader praised Kennedy's management of that crucial nuclear confrontation between US and USSR and saw in it the potential for détente. The paper reflects on the elements currently available for the interpretation of this piece of evidence and, with regard to the relationship between the two leaders, it argues that the way Kennedy handled the Cuban crisis 
may well have played a role in Dr. King's reassessment of Kennedy's evolving qualities of leadership - a view that King will further develop over the course of 1963 (in the most fruitful months of their cooperation) and will express after Dallas.

\section{INDEX}

Keywords: Martin Luther King, John Kennedy, Cuban missile crisis, Cuba, nuclear, Cold war, nonviolence, peace, letter, African Americans, US, Clarence B Jones, Khrushchev, reaction, 1962, Sixties

\section{AUTHOR}

\section{LEONARDO CAMPUS}

Leonardo Campus has a PhD in History (University of Rome La Sapienza). On the Cuban Missile Crisis and its perceptions he has published several research articles and the award-winning book: 'I sei giorni che sconvolsero il mondo. La crisi dei missili di Cuba e le sue percezioni internazionali'(Firenze: Le Monnier, 2014, pp.540). On this particular topic, he previously authored 'Missiles have no colour. African Americans' reactions to the Cuban missile crisis' (Cold War History, Feb. 2015). In 2012 he received a research grant from the JFK Institute for North American Studies of the Freie Universat, Berlin. He is also author of the book 'Non solo canzonette. L'Italia della Ricostruzione e del Miracolo attraverso il Festival di Sanremo' (Firenze: Le Monnier, 2015, pp.303), investigating Italy's 'boom' years through the lens of popular songs of the time. Research aside, he works as a public historian authoring programs for 'Rai Storia', History thematic channel of Italian State television. Email: campus.leonardo@gmail.com 